\title{
EXTENSIVELY DRUG RESISTANT TUBERCULOSIS (XDR TB)
}

\author{
Sarah Rahmayani Siregar ${ }^{1}$ \\ ${ }^{1}$ Fakultas Kedokteran, Universitas Malikussaleh \\ Corresponding author: sarahrahmayani00@gmail.com
}

\begin{abstract}
Abstrak
Tuberkulosis adalah penyakit infeksi kronis menular yang masih merupakan masalah kesehatan masyarakat di dunia termasuk Indonesia. Tuberkulosis (TB) sebagian besar akan mengalami penyembuhan dengan pengobatan. Namun tidak semua penyakit TB sembuh dengan pengobatan. Hal ini disebabkan pengobatan dari TB yang belum terlaksana dengan baik sehingga dapat pula menyebabkan terjadinya resistensi terhadap Obat Anti Tuberkulosis (OAT), berupa Multidrug Resistant Tuberkulosis (MDR TB) dan Extensively Drug Resistant Tuberculosis (XDR TB). XDR TB adalah TB yang disebabkan oleh strain yang resistensi terhadap isoniazid dan rifampisin, disertai resisten terhadap salah satu fluorokuinolon dan salah satu dari tiga obat injeksi lini kedua (amikasin, kapreomisin atau kanamisin). XDR TB diperkenalkan tahun 2006 ketika terjadi epidemi yang sangat fatal di Afrika Selatan. XDRTB dapat ditularkan melalui bakteri yang disebarkan oleh orang yang sudah terkena resistensi obat. Diagnosis XDR-TB ditegakkan dengan uji sensitiviti obat atau Drug Susceptibility Testing (DST), bukan sekedar berdasarkan gambaran foto toraks dan adanya faktor resiko yang ada pada seseorang. WHO telah merancang strategi Directly Observed Treatment Short Course (DOTS-Plus) untuk mengelola TB M/XDR di negara-negara miskin sumber daya. Revisi National Tuberculosis Programme (RNTCP) di bawah DOTS-Plus akan menggunakan rejimen pengobatan standar (STR) kategori IV, yang terdiri dari 6 obat (kanamisin, levofloxacin, etionamid, sikloserin, pirazinamid, dan etambutol) selama 6-9 bulan fase intensif dan 4 obat (levofloxacin, ethionamide, cycloserine, dan ethambutol) selama 18 bulan dari fase lanjutan. Penyembuhan tergantung pada tingkat resistensi obat, tingkat keparahan penyakit dan apakah sistem kekebalan pasien terganggu.
\end{abstract}

Kata kunci: extensively-drug-resistance-tuberculosis 


\title{
EXTENSIVELY DRUG RESISTANT TUBERCULOSIS (XDR TB)
}

\begin{abstract}
Tuberculosis is chronic infectious disease which still become public health problem in the world including Indonesia. Most of Tuberculosis (TB) will be healed by treatment. But not all TB diseases will be recovered by treatment. This is due to the treatment of TB that has not been implemented properly so that it can also causes resistance to Anti Tuberculosis Drugs (OAT), such as Multidrug Resistant Tuberculosis (MDR TB) and Extensive Drug Resistant Tuberculosis (XDR TB). XDR TB is defined as tuberculosis caused by strains of that resistant to rifampicin and isoniazid, which is also resitant to fluoroquinolone or any of the second line injectable drugs, such as capreomycin, kanamycin or amikacin. XDR TB was introduced in 2006 when an very fatal epidemic occurred in South Africa. XDR-TB can be transmitted by bacteria which was spread by people who have been exposed to drug resistance. The diagnosis of XDR TB is confirmed by drug susceptibility testing (DST), not just based on a chest X-ray picture and the risk factors that present in a person. World Health Organization (WHO) has designed Directly Observed Treatment Short Course (DOTS-Plus) strategy to manage $\mathrm{M} / \mathrm{XDR} \mathrm{TB}$ in resource-poor countries. The revised National Tuberculosis Program (RNTCP) under DOTS-Plus will use a standard IV treatment regimen (STR) category, consisting of 6 drugs (kanamycin, levofloxacin, etionamide, cycloserine, pyrazinamide, and ethambutol) for 6-9 months of intensive phase and 4 drugs (levofloxacin, ethionamide, cycloserine, and ethambutol) for 18 months of advanced phase. The recuperation depends on the level of drug resistance, the severity of the disease and the patient's immune system.
\end{abstract}

Keywords: extensively-drug-resistance-tuberculosis 


\section{PENDAHULUAN}

Tuberculosis paru adalah suatu penyakit menular langsung yang disebabkan oleh kuman Mycrobacterium Tuberculosis. Tuberkulosis (TB) paru mencakup $80 \%$ dari keseluruhan kejadian penyakit tuberkulosis, sedangkan $20 \%$ selebihnya merupakan tuberkulosis ekstrapulmonar. TB paru menjadi masalah kesehatan global, penyebab kesakitan jutaan penduduk setiap tahun dan menempati peringkat kedua penyebab kematian karena penyakit infeksi di dunia setelah HIV-AIDS. Secara global pada tahun 2016 terdapat 10,4 juta kasus insiden TB (CI 8,8 juta - 12, juta) yang setara dengan 120 kasus per 100.000 penduduk. Jumlah kasus baru TB di Indonesia sebanyak 420.994 kasus pada tahun 2017. Indonesia termasuk negara ke4 insiden TB paru tertinggi di dunia. ${ }^{1,2,3,4}$

Pengobatan TB yang tidak adekuat dapat menyebabkan timbulnya resistensi bakteri tuberkulosis terhadap Obat Anti Tuberkulosis (OAT). Di antara resistensi obat TB, multidrug-resistant (MDR)-TB merupakan penyakit dengan resistensi M. tuberculosis untuk isoniazid (INH) dan rifampisin (RIF), dua obat lini pertama anti-TB. Extensively drugresistant (XDR)-TB merupakan sub kelompok MDR-TB dengan basil tambahan yang resisten terhadap segala jenis fluroquinolone dan setidaknya salah satu dari tiga suntikan, kanamisin $(\mathrm{KM})$, amikasin $(\mathrm{PM})$ dan kapreomisin $(\mathrm{CM})^{5}$

Pentingnya XDR-TB pertama kali dilaporkan pada awal tahun 2006 dan kemudian dipublikasikan secara luas pada tahun yang sama ketika sebuah epidemi yang sangat fatal terjadi di Afrika Selatan. XDR-TB membawa prognosis yang sangat buruk, dengan kegagalan pengobatan dan tingkat kematian yang sangat tinggi. Pada Oktober 2006, WHO Global Task Force TB-XDR menyerukan tanggapan internasional terhadap krisis XDR-TB. Menurut WHO, telah diperkirakan bahwa sekitar 500.000 MDR-TB dan 40.000 kasus XDRTB muncul setiap tahun di seluruh dunia. ${ }^{6}$

Faktor penyebab timbulnya resisten OAT seperti diagnosis tidak tepat, pengobatan tidak menggunakan paduan yang tepat, dosis, jenis, jumlah obat dan jangka waktu pengobatan tidak adekuat, tidak teratur menelan obat anti tuberkulosis, dan, menghentikan pengobatan secara sepihak sebelum waktunya. ${ }^{3}$ 


\section{TINJAUAN PUSTAKA}

\section{Definisi Resistensi OAT (Obat Anti Tuberkulosis)}

Resistansi kuman M.tuberculosis terhadap OAT adalah keadaan di mana kuman tersebut sudah tidak dapat lagi dibunuh dengan OAT. TB resistan OAT pada dasarnya adalah suatu fenomena "buatan manusia", sebagai akibat dari pengobatan pasien TB yang tidak adekuat maupun penularan dari pasien TB resistan OAT. Terdapat lima kategori resistensi terhadap OAT yaitu:

a. Monoresisten: isolat M. tuberculosis kebal terhadap salah satu OAT lini pertama.

b. Poliresisten: isolat M. tuberculosis kebal dua atau lebih OAT lini pertama selain kombinasi rifampisin dan isoniazid.

c. Resisten obat ganda atau dikenal dengan multidrug-resistant tuberculosis (MDRTB): isolat M. tuberculosis resisten minimal terhadap isoniazid and rifampisin yaitu OAT yang paling kuat dengan atau tanpa disertai resisten terhadap OAT lainnya.

d. Resisten berbagai OAT / extensively drug-resistant tuberculosis (XDR-TB): Resistensi terhadap isoniazid dan rifampisin yang disertai resisten terhadap salah satu fluorokuinolon dan salah satu dari tiga obat injeksi lini kedua (amikasin, kapreomisin atau kanamisin).

e. Resisten rifampisin: resisten terhadap rifampisin yang dideteksi menggunakan metode fenotipik dan genotipik, dengan atau tanpa resisten terhadap OAT lain. Apapun dengan resisten rifampisin termasuk dalam kategori ini, baik monoresisten, poliresisten, resisten obat ganda atau resisten berbagai OAT.

f. Resisten OAT total / totally drug-resistant tuberculosis (TDR-TB): TB resisten dengan semua OAT lini I dan lini II.

Secara umum resistensi terhadap OAT dibagi menjadi: resistensi primer, resistensi sekunder dan resitensi inisial. Resistensi primer adalah resistensi M. tuberculosis terhadap OAT, dimana penderita tidak memiliki riwayat pengobatan OAT atau telah mendapat pengobatan OAT, namun kurang dari 1 bulan, sedangkan resistensi sekunder, pasien telah mempunyai riwayat pengobatan OAT minimal 1 bulan. Pada resistensi inisial, bila tidak diketahui pasti apakah pasien sudah ada riwayat pengobatan OAT sebelumnya atau belum pernah. $^{7}$ 


\section{EPIDEMIOLOGI}

Secara global pada tahun 2016 terdapat 10,4 juta kasus insiden TB paru yang setara dengan 120 kasus per 100.000 penduduk. Lima negara dengan insiden kasus tertinggi yaitu India, Indonesia, China, Philipina, dan Pakistan. Sebagian besar estimasi insiden TB pada tahun 2016 terjadi di kawasan Asia Tenggara (45\%) dimana Indonesia merupakan salah satu didalamnya dan $25 \%$ nya terjadi di kawasan Afrika. ${ }^{4}$

Indonesia pada tahun 2015, jumlah semua kasus tuberkulosis yang ditemukan sebesar 330.729 dan meningkat menjadi 351.893 pada tahun 2016. Sejak tahun 2016, tujuan program Tuberculosis Paru adalah mengakhiri epidemic TB Paru melalui penerapan strategi End TB. Strategi tersebut berupa mengurangi kematian akibat TB Paru sebesar 90\% pada tahun 2030 dan memutuskan kejadian kasus baru TB sebesar $80 \%{ }^{1}$

Pada Januari 2010, 58 negara telah melaporkan kepada WHO setidaknya terdapat 1 kasus XDR-TB. Di tahun 2008, 963 kasus XDR-TB dilaporkan pada WHO secara global dari 33 negara dibandingkan dengan 772 kasus dari 28 negara di tahun 2007. Banyak kasus XDRTB diyakini tidak pernah terdiagnosa dihubungkan dengan lemahnya kapasitas laboratorium untuk menguji resistensi terhadap obat lini kedua. Dari 27 negara yang tinggi MDR-TB, hanya 2 (Estonia dan Latvia) yang rutin menguji kasus MDR-TB untuk kerentanan obat lini kedua. 11 negara belum melaporkan kasus XDR-TB, dikarenakan kurangnya kapasitas laboratorium dibandingkan ketiadaan strain XDR-TB. Kasus XDR TB pada tahun 2015 terjadi di 105 negara. Sekitar 9,7\% pasien dengan MDR TB diperkirakan memiliki XDR TB. $^{6,8}$

\section{Penyebab resistensi OAT}

Kegagalan pada pengobatan poliresisten TB atau TB-MDR akan menyebabkan lebih banyak OAT yang resisten terhadap kuman M. tuberculosis. Kegagalan ini bukan hanya merugikan pasien tetapi juga meningkatkan penularan pada masyarakat. ${ }^{5}$ Faktor penyebab resitensi OAT terhadap kuman $M$. tuberculosis antara lain: ${ }^{9}$

A. Faktor mikrobiologik

1. Resisten yang natural

2. Resisten yang didapat

3. Amplifier effect

4. Virulensi kuman 
5. Tertular galur kuman - MDR

B. Faktor klinik

1. Penyelenggara kesehatan

a. Keterlambatan diagnosis.

b. Pengobatan tidak mengikuti guideline.

c. Penggunaan paduan OAT yang tidak adekuat yaitu karena jenis obatnya yang kurang atau karena lingkungan tersebut telah terdapat resistensi yang tinggi terhadap OAT yang digunakan misal rifampisin atau $\mathrm{INH}$.

d. Tidak ada guideline/pedoman.

e. Tidak ada / kurangnya pelatihan TB.

f.Tidak ada pemantauan pengobatan.

g. Fenomena addition syndrome yaitu suatu obat yang ditambahkan pada satu paduan yang telah gagal. Bila kegagalan ini terjadi karena kuman tuberkulosis telah resisten pada paduan yang pertama maka "penambahan" 1 jenis obat tersebut akan menambah panjang daftar obat yang resisten.

h. Organisasi program nasional TB yang kurang baik.

2. Obat

a. Pengobatan TB jangka waktunya lama lebih dari 6 bulan sehingga membosankan pasien.

b. Obat toksik menyebabkan efek samping sehingga pengobatan kompllit atau sampai selesai gagal.

c. Obat tidak dapat diserap dengan baik misal rifampisin diminum setelah makan, atau ada diare.

d. Kualitas obat kurang baik misal penggunaan obat kombinasi dosis tetap yang mana bioavibiliti rifampisinnya berkurang.

e. Regimen / dosis obat yang tidak tepat.

f.Harga obat yang tidak terjangkau.

g. Pengadaan obat terputus.

3. Pasien

a. Kurangnya informasi atau penyuluhan

b. Kurang dana untuk obat, pemeriksaan penunjang dll

c. Efek samping obat

d. Sarana dan prasarana transportasi sulit / tidak ada 
e. Masalah sosial

f. Gangguan penyerapan obat

C. Faktor program

1. Tidak ada fasilitas untuk biakan dan uji kepekaan

2. Amplifier effect

3. Tidak ada program DOTS-PLUS

4. Program DOTS belum berjalan dengan baik

5. Memerlukan biaya yang besar

6. Faktor AIDS-HIV

7. Kemungkinan terjadi TB-MDR lebih besar

8. Gangguan penyerapan

9. Kemungkinan terjadi efek samping lebih besar

D. Faktor kuman

Kuman M. tuberculosis super strains

1. Sangat virulen

2. Daya tahan hidup lebih tinggi

3. Berhubungan dengan TB-MDR

\section{Mekanisme Resistensi pada M. tuberculosis}

Resistensi bakteri $M$. tuberculosis terhadap OAT adalah keadaan ketika bakteri tidak dapat dibunuh dengan OAT. Resistensi obat pada TB bukan hanya disebabkan oleh pengobatan yang tidak adekuat atau gagal, namun juga disebabkan oleh munculnya strain resisten yang ditransmisikan oleh penderita MDR-TB. Strain yang resisten muncul akibat adanya perubahan atau mutasi pada gen-gen tertentu dalam genom M. tuberculosis. Gen-gen ini merupakan target dari mekanisme kerja OAT.

Mycobacterium tuberculosis memiliki karakteristik pertumbuhan yang lambat, dorman, memiliki komponen dinding sel yang kompleks, merupakan organisme intraseluler serta memiliki homogenitas genetik. Karakteristik pertumbuhan yang lambat dan dorman sangat berkontribusi dalam kronisitas infeksi yang ditimbulkan. Hal ini juga berdampak pada lamanya masa terapi selain juga menjadi kendala terutama dalam hal menumbuhkan bakteri basil Gram positif ini. Keadaan dormansi merupakan akibat dari ditekannya jalur metabolik bakteri akibat aktivasi sistem imun seluler. Mekanisme ini merupakan bentuk pertahanan terhadap infeksi namun tidak dapat mengeradikasi infeksi. Apabila terjadi penurunan sistem 
imun dan proses penuaan, maka infeksi dapat teraktivasi. Resistensi alamiah terhadap banyak antibiotika merupakan salah satu keunikan yang dimiliki oleh M. tuberculosis. Resistensi ini terjadi akibat adanya dinding sel yang sangat hidrofobik dan berperan sebagai barrier permeabilitas.

Mycobacterium tuberculosis memiliki kemampuan untuk mengembangkan resistensi secara alamiah terhadap berbagai antibiotika. Mycobacterium tuberculosis mengembangkan mekanisme resistensi yang berbeda dengan bakteri lain pada umumnya. Resistensi hanya akan menguntungkan bakteri pada saat terpapar dengan obat target. Pada paparan OAT yang tidak adekuat, bakteri yang sensitif akan mati dan bermutasi kemudian akan berkembang biak dengan pesat tanpa adanya persaingan yang berarti dalam hal nutrisi. ${ }^{10}$

1. Mekanisme resistensi terhadap isoniazid

Obat ini merupakan OAT lini pertama yang mulai diperkenalkan tahun 1952 dan merupakan OAT utama karena memiliki efek bakterisid yang kuat. Tidak seperti rifampisin, isoniazid hanya aktif terhadap basil replikasi yang aktif secara metabolik. Resistensi terhadap INH disebabkan oleh adanya mutasi pada sejumlah gen, yaitu katG, inh, kasA dan NDH Gen katG berperanndalam mengkode enzim katalase- peroksidase yang dibutuhkan untuk mengaktivasi Isoniazid (INH) yang masuk ke dalam tubuh sebagai pro-drug. Dalam mekanisme kerja menghambat sintesis mycolic acid, INH yang teraktivasi menghambat enzim NADH- dependent enoyl-ACP reductase yang dikode oleh gen inhA. ${ }^{11,12}$

Mutasi gen katG dan inhA merupakan mekanisme molekuler resistensi isoniazid yang

paling utama. ${ }^{8}$ Mutasi yang paling sering dijumpai pada katG adalah mutasi asam amino Serin menjadi Threonin pada kodon 315 (Ser315Thr). Mutasi pada inhA padabagian promotor (posisi $-15 \mathrm{C} / \mathrm{T}$ ) merupakan mutasi yang paling banyak ditemukan pada resistensi INH dan mutasi ini juga mengakibatkan resistensi silang dengan etionamid karena memiliki target kerja obat yang sama. ${ }^{11,12}$

\section{Mekanisme Resistensi Terhadap Rifampisin}

Rifampicin adalah turunan rifamycin yang diperkenalkan pada tahun 1972 sebagai agen antituberkulosis. Rifampicin adalah salah satu antibiotik anti-TB yang paling efektif dan bersama dengan isoniazid merupakan dasar dari rejimen pengobatan multi-obat TB. Target rifampisin pada $\mathrm{M}$. tuberculosis adalah b subunit dari $R N A$ polymerase, di mana ia mengikat dan menghambat pemanjangan utusan RNA. Karakteristik penting dari rifampisin adalah bahwa rifampisin bekerja terhadap bakteri yang tumbuh aktif maupun yang tidak aktif. ${ }^{11}$ 
RNA polymerase tersusun atas 4 subunit berbeda $\left(\alpha, \beta, \beta^{\prime}\right.$ dan $\left.\sigma\right)$ dan dikode oleh gen rpoA, rpoB, rpoC dan rpoD. Kebanyakan isolat klinis resisten rifampisin mengalami mutasi pada gen rpoB sehingga terjadi penurunan afinitas terhadap obat sehingga resistensi berkembang. Sekitar 96\% isolat M. tuberculosis resisten terhadap rifampisin. Penyebabnya adalah mutasi pada daerah yang disebut "hot-spot region" dari daerah inti 81-bp (rifampicin resistance-determining region atau RRDR) dari rentang kodon 507-533 gen rpoB. Mutasi tersebut mengubah struktur primer rpoB. Mutasi missense di kodon 513, 526 dan 531 adalah mutasi yang paling umum berhubungan dengan resistensi rifampisin. Mutasi pada kodon tersebut menghasilkan resistensi tingkat tinggi terhadap rifampisin. ${ }^{8}$

3. Mekanisme Resistensi terhadap Pirazinamid

Pyrazinamide diperkenalkan ke dalam pengobatan TB pada awal 1950-an dan sekarang menjadi bagian dari rejimen lini pertama standar untuk mengobati TB paru. Pirazinamid memiliki aktivitas sterilisasi pada awal terapi yang mampu membunuh bakteri persisten dan mempersingkat masa terapi dari 9 bulan menjadi 6 bulan. Pirazinamid adalah analog struktural nikotinamid dan pro-obat yang perlu diubah menjadi bentuk aktif yaitu asam pyrazinoik, oleh enzim pyrazinamidase/nicotinamidase (PZase). Resistensi terhadap pyrazinamide terjadi karena adanya mutasi gen pncA. Mekanisme resistensi pirazinamid berkaitan dengan hilangnya aktivitas pirazinamidase sehingga tidak banyak pirazinamid yang diubah menjadi asam pirazinoat. ${ }^{12,13}$

4. Mekanisme resistensi terhadap etambutol

Etambutol pertama kali diperkenalkan sebagai obat anti-TB pada tahun 1966 dan menjadi bagian dari regimen lini pertama OAT.Etambutol bersifat bakteriostatik terhadap multiplikasi basil yang mengganggu biosintesis arabinogalactan di dinding sel. Pada $\mathrm{M}$. tuberculosis, gen embCAB, berperan sebagai operon, kode untuk transferase arabinosyl, yang terlibat dalam sintesis arabinogalactan, untuk menghasilkan akumulasi intermediate darabinofuranosyl-P-decaprenol. ${ }^{14}$

Mekanisme resistensi etambutol diketahui terkait dengan adanya mutasi pada gen embB. Mutasi pada embB kodon 306 (embB306) menjadi yang paling umum pada kebanyakan penelitian. Berbagai penelitian telah mengidentifikasi adanya 5 mutasi pada kodon 306 (ATG), yaitu ATG $\square$ GTG/CTG/ATA, ATC dan ATT. Akibatnya metionin (ATG) diganti oleh valin, leusin atau isoleusin.

5. Mekanisme Resistensi pada Streptomisin 
Streptomisin merupakan golongan aminoglikosida yang diisolasi dari Streptomyces griseus. Streptomycin adalah aminocyclitol glikosida yang aktif melawan basil yang tumbuh aktif dan cara kerjanya adalah dengan menghambat inisiasi sintesis protein. Streptomisin bekerja pada tingkat subunit 30S dari ribosom pada protein ribosom S12 dan 16S rRNA yang dikodekan oleh gen rpsL dan rrs. ${ }^{11}$

Mekanisme utama resistensi terhadap streptomisin diyakini dimediasi melalui mutasi pada gen rpsL dan rrs, yang masing-masing mengkode protein ribosom S12 dan 16S rRNA. Mutasi umumnya terjadi di kodon 43 dan 88 pada gen rpsL serta di daerah spesifik yaitu loop 530 serta daerah 912 pada gen rrs. Perubahan asam amino Lisin menjadi Arginin atau Threonin pada kodon dan perubahan Lisin menjadi Arginin atau Glutamin pada kodon 88, merupakan bentuk mutasi yang sering ditemukan pada isolat Mycobacterium tuberculosis yang resisten terhadap Streptomisin. ${ }^{15}$

6. Mekanisme resistensi terhadap fluoroquinolon

Fluoroquinolones saat ini digunakan sebagai obat lini kedua untuk mengobati kasus MDR TB. Ciprofloxacin dan ofloxacin adalah turunan sintetik dari senyawa induk asam nalidiksat, yang ditemukan sebagai produk dalam pemurnian chloroquin. Kuinolon generasi baru seperti moksifloksasin dan gatifloksasin sedang dievaluasi dalam uji klinis dan diusulkan sebagai antibiotik lini pertama dengan tujuan memperpendek lama pengobatan TB. ${ }^{11}$

Mekanisme utama penyebab munculnya resistensi fluoroquinolone pada $M$. tuberculosis adalah terjadinya mutasi kromosom di quinolone resistance determining region (QRDR) dari gen gyrA atau gyrB. Quinolone resistance determining region adalah suatu daerah terlindung di gen gyrA (320 bp) dan gen gyrB (375 bp) yang merupakan titik interaksi antara fluorokuinolon dan gyrase (Ginsburg dkk., 2003). Mutasi paling sering ditemukan pada kodon 90 dan 94 gen gyrA. Selain itu, mutasi juga dilaporkan terjadi pada kodon 74, 88 dan $91 .^{8}$

7. Mekanisme resistensi terhadap kapreomisin, kanamisin, amikasin, dan viomisin

Keempat antibiotik ini memiliki mekanisme kerja yang sama yaitu dengan menghambat sintesis protein. Kanamycin dan amikacin adalah aminoglikosida, kapreomisin dan viomisin adalah antibiotik peptida siklik. Keempatnya adalah obat lini kedua yang digunakan dalam pengelolaan TB-MDR. ${ }^{11}$

Mutasi paling umum ditemukan terjadi pada gen rrs (pengkode 16S rRNA) pada kodon 1400 dan 1401. Mutasi ini menyebabkan resistensi kanamisin dan amikasin tingkat tinggi. 
Resistensi viomisin pada $M$. smegmatis disebabkan oleh perubahan pada subunit $30 \mathrm{~S}$ atau 50S ribosomal. Mutasi pada gen rrs sebagai pengkode 16S rRNA dikaitkan dengan resistensi viomisin dan kapreomisin, khususnya perubahan nukleotida $\mathrm{G} \square \mathrm{A}$ atau $\mathrm{G} \square \mathrm{T}$ pada kodon $1473 .^{8}$

Tabel 1 Obat Anti TB dan gen terkait

\begin{tabular}{|c|c|c|}
\hline Drug & Giene & Merhanism Involved \\
\hline Isoniazid & kati. inlist & Catalase peroxidase; enoyl reductase \\
\hline Rifampicin & rpos & RNA polymerase \\
\hline Pyrazimamide & pucd, rps & Pyrazirumidase; ribosomal protein 1 \\
\hline Ethambutol & $a n b B$ & Arabinosyl transferase \\
\hline Streptomycin & rpsL.,rrs, gidB & $\begin{array}{l}\text { \$12 ribosomal protein, } 16 \mathrm{~A} \text { rRNA, } \\
\text { 7-methylguanosine methyltransferase }\end{array}$ \\
\hline Quinolones & girA, gir $B$ & DNA gyrase \\
\hline Capreomycin & $m s, l y A$ & $16 \mathrm{~S}$ rRNA, rRNA methyltransferase \\
\hline Kanamycim/Amikacin & rrs & $16 \mathrm{~S}$ rRNA \\
\hline Ethionamido & ethat & Enoyl-ACP reductase \\
\hline Para-aminosalicylic acid & liny d folc: & Thymidylate synthase $A$ \\
\hline
\end{tabular}

\section{Penularan XDR TB}

XDR-TB dapat ditularkan melalui bakteri yang disebarkan oleh orang yang sudah terkena resistensi obat. Jalan kedua perkembangan MDR atau XDR-TB adalah dari pasien sendiri yang berkembang menjadi resisten. Hal ini dapat terjadi pada putus obat OAT atau pengobatan tidak terkontrol. Ditemukan juga apabila program kontrol TB tidak dikelola dengan baik, contohnya saat pasien tidak didukung untuk mendapatkan pengobatan yang tuntas, penyedia sarana kesehatan memberi pengobatan yang salah, dosis yang salah atau periode pengobatan yang terlalu singkat, ketersediaan obat yang terbatas, atau kualitas obat yang buruk.

Tidak ada perbedaan penyebaran XDR-TB dengan jenis TB yang lain. Penyebaran bakteri TB bergantung dari beberapa faktor yaitu jumlah dan konsentrasi orang terinfeksi 
hidup di lingkungan yang sama dengan terdapatnya orang yang beresiko terkena TB (misalnya orang dengan HIV-AIDS). Resiko penyebaran kuman TB meningkat dimana terdapat konsentrasi bakteri TB yang tinggi, misalnya di lingkungan tertutup dan padat, rumah sakit, atau penjara. Resiko akan lebih tinggi dengan ventilasi yang buruk. ${ }^{16}$

\section{Diagnosis XDR TB}

Tuberkulosis yang resistan terhadap obat sering tidak terdeteksi dan tidak diobati di banyak negara. Pilihan awal pengobatan yang tepat merupakan penentu penting dari hasil yang menguntungkan, dan penentuan cepat resistensi obat dapat memungkinkan pendekatan khusus untuk pengobatan di awal perjalanan penyakit dan berpotensi dapat mengurangi morbiditas, mortalitas dan infeksi. Diagnosis MDR-TB dan XDR-TB terhambat oleh tidak adanya teknik diagnostik cepat yang efektif dan terjangkau untuk sensitivitas obat. Beberapa pendekatan, fenotipik dan molekuler, telah dieksplorasi untuk mengembangkan metode yang cepat, andal dan akurat untuk deteksi cepat resistensi obat pada TB. Metode-metode ini juga harus dievaluasi dan diterapkan di daerah dengan insiden tinggi. ${ }^{17}$

Diagnosis XDR-TB sangat tergantung pada akses pasien untuk perawatan layanan kesehatan. Jika bakteri TB ditemukan di dalam dahak, diagnosis TB dapat ditentukan dalam satu atau dua hari, namun penemuan bakteri ini tidak akan mampu membedakan antara yang peka dan yang resisten terhadap obat TB. Diagnosis XDR-TB ditegakkan dengan uji sensitivitas obat atau drug susceptibility testing (DST), bukan sekedar berdasarkan gambaran foto toraks dan adanya faktor resiko yang ada pada seseorang.Untuk mengevaluasi resistensi obat, dibutuhkan bakteri untuk dibudidayakan dan diuji di laboratorium yang sesuai. Diagnosis akhir dengan cara ini untuk TB, dan terutama untuk XDR-TB, dibutuhkan waktu 6 sampai 16 minggu. ${ }^{16}$ Namun, DST memiliki keterbatasan yaitu tekniknya kompleks, sulit untuk dilakukan secara akurat bahkan dengan tenaga terampil dan fasilitas laboratorium berstandar tinggi. ${ }^{18}$

\section{Tatalaksana XDR TB}

World Health Organization telah merancang strategi Directly Observed Treatment Short Course (DOTS-Plus) untuk mengelola TB M/XDR di negara-negara miskin sumber daya. DOTS-Plus adalah komponen integral dari RNTCP (Revisi National Tuberculosis Programme) untuk mengelola M/XDR-TB. RNTCP di bawah DOTS-Plus akan menggunakan rejimen pengobatan standar (STR) kategori IV, yang terdiri dari 6 obat (kanamisin, 
levofloxacin, etionamid, sikloserin, pirazinamid, dan etambutol) selama 6-9 bulan fase intensif dan 4 obat (levofloxacin, ethionamide, cycloserine, dan ethambutol) selama 18 bulan dari fase lanjutan. Asam P-aminosalisilat (PAS) termasuk dalam rejimen sebagai obat pengganti jika ada obat bakterisidal (kanamisin, levofloxacin, pirazinamid, atau etionamida) atau 2 obat bakteriostatik (etambutol dan sikloserin) tidak dapat ditoleransi. Rejimen IV ini sangat cocok untuk negara dengan prevalensi TB tinggi dan juga negara berpenghasilan rendah hingga menengah. Obat suntik harus diberikan setidaknya 6 bulan dan seluruh durasi pengobatan minimal 18 bulan setelah konversi dahak. Pengobatan lini kedua yang sepenuhnya standar telah terbukti layak dan hemat biaya dalam pengobatan M / XDR-TB. ${ }^{18}$

Tabel 2 Dosis Obat XDR TB

\begin{tabular}{|c|c|}
\hline Obat & Dosis \\
\hline \multicolumn{2}{|l|}{ 1. First line oral agents } \\
\hline Ethambutol $^{\mathrm{A}}$ & $1200 \mathrm{mg}(15 \mathrm{mg} / \mathrm{kg})$ \\
\hline Pyrazinamide $^{\mathrm{A}}$ & $1500 \mathrm{mg}(20-30 \mathrm{mg} / \mathrm{kg})$ \\
\hline \multicolumn{2}{|l|}{ 2. First line injectable agents } \\
\hline Streptomycin ${ }^{\mathrm{B}}$ & $0.75-1 \mathrm{~g}$ IM (15 mg/kg) \\
\hline \multicolumn{2}{|l|}{ 3. Second line injectable agents } \\
\hline Amikacin $^{\mathrm{B}}$ & $0.75-1 \mathrm{~g} \mathrm{IM}(15 \mathrm{mg} / \mathrm{kg})$ \\
\hline Capreomycin $^{\mathrm{B}}$ & $0.75-1$ g IM $(15 \mathrm{mg} / \mathrm{kg})$ \\
\hline Kanamycin ${ }^{\mathrm{B}}$ & $0.75-1 \mathrm{~g} \mathrm{IM}(15 \mathrm{mg} / \mathrm{kg})$ \\
\hline \multicolumn{2}{|l|}{ Fluroquinolones } \\
\hline 4. First generation fluroquinolones ${ }^{\mathrm{C}}$ & $1.5 \mathrm{~g}(750 \mathrm{mg} \mathrm{BD})$ \\
\hline Ciprofloxacin & $800 \mathrm{mg}(400 \mathrm{mg} \mathrm{BD})$ \\
\hline \multicolumn{2}{|l|}{ Ofloxacin } \\
\hline \multicolumn{2}{|l|}{ 5. Later generation fluroquinolones } \\
\hline Levofloxacin & $500 \mathrm{mg}$ OD \\
\hline Sparfloxacin & $200 \mathrm{mg}$ BD \\
\hline Moxifloxacin $^{*}$ & $400 \mathrm{mg}$ OD \\
\hline 6. Other second line oral agents & $250-500 \mathrm{mg} \mathrm{BD}$ \\
\hline Cycloserine $^{\mathrm{A}}$ & $500-750 \mathrm{mg}$ OD $(10-15 \mathrm{mg} / \mathrm{kg})$ \\
\hline Ethionamide $^{\mathrm{A}}$ & $5 \mathrm{~g} \mathrm{BD}(300 \mathrm{mg} / \mathrm{kg})$ \\
\hline \multicolumn{2}{|l|}{ Paraaminosalicylic acid (PAS) ${ }^{\mathrm{D}}$} \\
\hline \multicolumn{2}{|l|}{ 7. Other agents } \\
\hline Amoxycillin-clavulanate $^{\mathrm{A}}$ & $100-300 \mathrm{mg}$ \\
\hline Clarithromycin ${ }^{\mathrm{B}}$ & $300-450 \mathrm{mg}$ \\
\hline Clofazimine $^{\mathrm{D}}$ & $600-900 \mathrm{mg}$ \\
\hline Rifabutin $^{\mathrm{D}}$ & $600 \mathrm{mg} \mathrm{BD}$ \\
\hline Terizidone $^{\mathrm{A}}$ & \\
\hline
\end{tabular}




\begin{tabular}{lc}
\hline Obat & Dosis \\
\hline Linezolid $^{\mathrm{B}}$ & \\
8. ATP synthase inhibitors & \\
Diarylquinolones (TMC207) & \\
\hline
\end{tabular}

Terapi empiris berdasarkan pengobatan dan riwayat kontak, harus dimulai tergantung pada hasil DST (tes kerentanan obat). Setelah hasil tes kerentanan obat tersedia, rejimen harus disesuaikan. ${ }^{19}$

1. Semua obat diberikan berdasarkan pengamatan langsung.

2. Pasien harus masuk untuk fase intensif 6-9 bulan dan dipantau untuk fase lanjutan minimal 18 bulan.

3. Perawatan harus mengandung setidaknya 5 obat yang membuat pasien rentan. Agen lini pertama dengan laporan sensitivitas yang baik harus lebih disukai daripada obat lini kedua. Jika 5 obat yang efektif tidak tersedia, dokter harus mempertimbangkan obat yang tidak terpapar sebelumnya atau paparan kurang dari 30 hari.

4. Durasi pengobatan harus setidaknya 18 bulan untuk agen oral dan setidaknya 8 bulan setelah konversi kultur untuk obat injeksi.

5. Jika rejimen tidak dapat mengandung 5 obat yang efektif, strategi penguatan harus dilaksanakan, yaitu:

a. Memperpanjang durasi pengobatan dengan agen injeksi.

b. Memperpanjang durasi seluruh rejimen dengan penambahan obat lain. Obat yang ditambahkan termasuk Rifabutin yang memiliki aktivitas dipertanyakan terhadap tuberkulosis yang resistan terhadap beberapa obat.

6. Semua pasien harus menjalani pemeriksaan kultur setiap bulan.

7. Kunjungan klinis bulanan harus dilakukan saat pasien menggunakan terapi suntik Pasien dengan sputum positif yang persisten, resisten terhadap banyak OAT, dan lesi yang terlokalisasi diindikasikan reseksi bedah. Reseksi dapat dilakukan setelah pemberian terapi OAT paling sedikit 2 bulan dengan tujuan menurunkan tingkat infeksi bakteri pada jaringan paru sekitarnya. Setelah reseksi, OAT sebaiknya tetap diberikan 12-24 bulan kemudian 20

\section{Pencegahan}

Program pengendalian TB nasional yang bekerja dengan semua layanan kesehatan dapat mencegah TB-XDR dengan memastikan bahwa semua praktisi yang bekerja dengan 
Odha mematuhi Standar Internasional untuk Perawatan TB. Ini menekankan memberikan diagnosis dan pengobatan yang tepat untuk semua pasien TB, termasuk pasien dengan TB yang resistan terhadap obat; memastikan pasokan teratur, tepat waktu dari semua obat antiTB; manajemen obat anti-TB yang tepat dan memberikan dukungan kepada pasien untuk memaksimalkan kepatuhan terhadap rejimen yang diresepkan; merawat kasus MDR / XDRTB dalam layanan dengan ventilasi yang tepat, dan meminimalkan kontak dengan pasien lain, terutama dengan HIV, terutama pada tahap awal sebelum pengobatan memiliki kesempatan untuk mengurangi infeksi. ${ }^{21}$

World Health Organization merekomendasikan strategi DOTS dalam penatalaksanaan kasus TB, selain relative tidak mahal dan mudah, strategi ini dianggap dapat menurunkan risiko terjadinya kasus resistensi obat terhadap TB. Pencegahanan yang terbaik adalah dengan standarisasi pemberian regimen yang efektif, penerapan strategi DOTS dan pemakaian obat FDC adalah yang sangat tepat untuk mencegah terjadinya resistensi OAT. ${ }^{22}$

The WHO Global Task Force for XDR-TB di Jenewa 9-10 Oktober 2006 merumuskan sebagai berikut: ${ }^{23}$

a. Pencegahan XDR-TB dengan memperkuat kontrol dasar terhadap TB dan HIV. Strategi baru dan perencanaan global stop TB sangat penting sebagai pedoman intervensi utama ini.

b. Peningkatan penatalaksanaan terhadap pasien suspek XDR-TB dengan memperbanyak fasilitas laboratorium yang memadai, termasuk uji sensitivitas OAT yang cepat untuk mendeteksi strain MDR-TB baik di area prevalensi HIV tinggi maupun rendah.

c. Memperkuat penatalaksanaan XDR-TB dan rancangan pengobatan HIV positif dan negatif. Intervensi ini akan didasarkan atas penerapan protokol baru WHO untuk kasus TB resisten dengan OAT lini kedua yang adekuat dan pendekatan dan pengawasan individual.

d. Standarisasi definisi XDR-TB dan diharapkan penggunaan definisi baru secara global akan meningkatkan validasi data dan perbandingannya.

e. Peningkatan kontrol dan proteksi terhadap infeksi HIV. Intervensi ini dicapai melalui pencegahan penularan MDR-TB terutama pasien positif HIV terutama pada daerah prevalensi HIV tinggi.

f. Pelaksanaan surveillance XDR-TB segera sehingga dibutuhkan laboratorium rujukan nasional dan internasional untuk mencapai terselenggaranya survei global secepatnya mulai awal 2007. 
g. Inisiasi aktivitas advokasi komunikasi dan mobilisasi sosial karena hal yang sangat penting adalah meningkatkan informasi dan kewaspadaan terhadap TB khususnya XDRTB.

\section{PROGNOSIS}

Beberapa program pengendalian TB telah menunjukkan bahwa penyembuhan dimungkinkan untuk sekitar 30\% hingga 50\% orang yang terkena dampak. Pasien TB-XDR dapat disembuhkan, tetapi dengan obat yang tersedia saat ini, kemungkinan keberhasilannya jauh lebih kecil daripada pasien dengan TB biasa atau bahkan TB-MDR. Penyembuhan tergantung pada tingkat resistensi obat, tingkat keparahan penyakit dan apakah sistem kekebalan pasien terganggu. ${ }^{24}$

Pasien yang terinfeksi HIV mungkin memiliki angka kematian yang lebih tinggi. Diagnosis dini dan akurat adalah penting sehingga pengobatan yang efektif diberikan sesegera mungkin. Perawatan yang efektif mensyaratkan bahwa pilihan obat lini kedua yang baik tersedia untuk dokter yang memiliki keahlian khusus dalam menangani kasus-kasus tersebut. $^{21}$

\section{DAFTAR PUSTAKA}

1. Budi I, Ardhila Y, Sari I, Septiawaty D, 2018. Analisis Faktor Resio Kejadian Penyakit Tuberkulosis bagi Masyarakat Daerah Kumuh Kota Palembang. Jurnal Kesehatan Lingkungan Indonesia:17(2):87-94.

2. Djojodibroto D, Respirologi, EGC, Jakarta, 2009.

3. Nugrahaeni D, Malik U,2015. Analisis Penyebab Resistensi Obat Anti Tuberkulosis. Jurnal Kesehatan Masyarakat:11(1):8-15.

4. Pusat Data dan Informasi Kementerian Kesehatan Republik Indonesia, Infodatin Tuberkulosis, 2018, didapat dari http://www.pusdatin.kemkes.go.id/pdf.php?id=18101500001

5. Kementerian Kesehatan Republik Indonesia, Petunjuk Teknis Manajemen Terpadu Pengendalian Tuberkulosis Resistan Obat: Direktorat Jenderal Pengendalian Penyakit dan Penyehatan Lingkungan, 2018.

6. Elorza E, Guillen S, 2010. Multidug Resistant Tb and Extensively Drug Resistant TB. Rev Esp sanid Penit:12:91-98.

7. Carolia N, Mardhiyah A, 2016. MultiDrug Resistant Tuberculosis pada Pasien Drop Out dan Tatalaksana OAT Lini Kedua. Jurnal Kedokteran Universitas Lampung:5(2):11-15. 
8. Irianti R, Kuswandi, Y Nanang, Kusumaningtiyas R, Mengenal anti Tuberkulosis, UGM, Yogyakarta, 2016.

9. Perkumpulan Pemberantasan Tuberkulosis Indonesia, Jurnal Tuberkulosis Indonesia, 2010 .

10. Rinanda T, 2015. Kajian Molekuler Mekamisme Resistensi Mycobacterium tuberculosis. Jurnal Kedokteran Universitas Syiah Kuala:15 (3): 162-167.

11. Palomino J, martin A, 2014. Drug Resistance Mechanisms in Mycobacterium tuberculosis. Antibiotics: 3: 317-340.

12. Silva P, Palomino J, 2011. Molecular Basis and Mechanisms of Drug Resistance in Mycobacterium tuberculosis: Classical and New Drugs. Journal of Antimicrobial Chemotherapy: 66 (7): 1417-1430.

13. Jhonson et al., 2009, Drug Resistance in Mycobacterium tuberculosis. Current Issues in Molecular Biology: 8: 97-112.

14. Dookie et al.,2018. Evolution of Drug Resitance in Myobacterium tuberculosis: a review on the molecular determinants of resistance and implications for personalized care. Journal of Antimicrobial Chemotherapy: 73 (5): 1138-1151.

15. Zhang Y, Yew W, 2009. Mechanisms of Drug Resistance in Myobacterium tuberculosis, International Journal of Tuberculosis and Lung Disease: 13 (11): 1320-1330.

16. Stop TB partnership, Extensively drug-resistant tuberculosis (XDR-TB), World Health Organization, 2007.

17. Migliori G, Matteli A, Crillo D, Pai M, 2008. Diagnosis of Multidrug Resistant Tuberculosis and Extensively Drug Resistant Tuberculosis: Current Standards and Challenges, Canadian Journal of Infectious Diseases and Medical Microbiology: 19 (2): 169-172.

18. Prasad R, 2012. Multidrug and Extensively Drug Resistant Tuberculosis Management: Evidences and Controversies. Lung India: 29 (2): 154-159.

19. Marwar A et al., 2011, Extensively Drug Resistant Tuberculosis (XDR-TB): A Potential Threat, Journal of Basic and Clinical Pharmacy: 002 (001): 27-32.

20. Adriansyah R, Singh G, Amin Z, Uyainah A, 2009. Peran Intervensi Bedah dalam Tatalaksana Tuberkulosis Paru Resisten Obat, The Indonesian Journal Chest and critical Emergency Medicine: 2 (3): 130-133. 
21. Word Health Organization, Drug Resistance Tuberculosis: XDR TB- FAQ, 2009, didapat dari file:///D:/xdr\%20tb/WHO\%20\%20\%20Drug-resistant\%20TB\%20\%20XDRTB\%20FAQ.htm.

22. Alfin S, 2012, Multidrug Resistant Tuberkulosis; Sebuah Tinjauan Kepustakaan, Fakultas Kedokteran Universitas Syiah Kuala.

23. World Health Organization, Multidrug and extensively drug-resistant TB (M/XDR-TB) . The WHO global report on surveillance and response. Genewa, World Health Organization, 2010.

24. Centers for Disease Control and Preventation, Extensively Drug Resistance Tuberculosis (XDR TB), 2016, didapat dari file:

//D:/xdr\%20tb/Fact\%20Sheets\%20\%20\%20DrugResistant\%20TB\%20\%20\%20Extensiv ely\%20DrugResistant\%20Tuberculosis\%20(XDR\%20TB)\%20\%20\%20TB\%20\%20\%20 CDC.htm. 